\title{
Short Communication: Cross-species amplification of microsatellite markers developed for Jatropha curcas within five species of Jatropha
}

\author{
DARMAWAN SAPTADI ${ }^{1, \bullet}$, BAMBANG HELIYANTO ${ }^{2}$, SUDARSONO ${ }^{3, \bullet \bullet}$ \\ ${ }^{1}$ Plant Breeding Laboratory, Department of Agronomy, Faculty of Agriculture, Universitas Brawijaya. Jl. Veteran, Malang 65145, East Java, Indonesia. \\ Tel.: +62-341-551665, •email: darmawan.fp@ub.ac.id \\ ${ }^{2}$ Indonesian Sweetener and Fiber Crops Research Institute. Jl. Raya Karangploso, PO BOS 199, Malang 65152, East Java, Indonesia \\ ${ }^{3}$ PMB Lab., Department of Agronomy and Horticulture, Faculty of Agriculture, Institut Pertanian Bogor. Jl. Meranti, Darmaga Campus, Bogor 16680, \\ West Java, Indonesia. Tel/fax.: +62-251-8629353, •`email: sudarsono_agh@apps.ipb.ac.id
}

Manuscript received: 7 September 2020. Revision accepted: 7 October 2020.

\begin{abstract}
Saptadi D, Heliyanto B, Sudarsono. 2020. Short Communication: Cross-species amplification of microsatellite markers developed for Jatropha curcas within five species of Jatropha. Biodiversitas 21: 5072-5076. The transferability of SSR markers can be used to access the genetic diversity of related species. There are four close relatives of Jatropha curcas L in Indonesia, which can be utilized as a new diversity source through the interspecific crossing. This research was conducted to determine the ability of crossspecies amplification of SSR markers developed from J. curcas to other Jatropha species (J. integerrima, J. multifida, J. gossypifolia, J. podagrica). It also investigated the relationship between these species. Out of 28 primers checked, 11 primers showed cross-species amplification in all the species tested. Primer pairs EU099519, EU099528, and EU099525 have no transferability to other species. The overall percentage of polymorphism (PP) among all species tested was $95 \%$, with the mean genetic similarity (GS) was 0.34 . Least PP $(17.35 \%)$ and highest GS (0.60) was found between pairs of J. podagrica and J. multifida. The correlation between the PP with GS was relatively high (0.75). The farthest and closest genetic distance was found between $J$. curcas/J. gossypifolia and $J$. podagrica/J. multifida, respectively. Further, selected primers from this study can be utilized in species differentiation, molecular identification of interspecific hybrids, and exploiting the genetic resource.
\end{abstract}

Keywords: Cross-species amplification, SSR marker, interspecific crossing

\section{INTRODUCTION}

The Jatropha genus has diverse phenotypes that include various growth habits and either monoecious or dioecious flowering types. The genus is divided into subgenera: subgenus Jatropha and subgenus Curcas (Heller 1996). In the tropics, 150-175 species of the woody and shrub types of Jatropha exist (Dehgan 1982). In the last decades, Jatropha curcas has become an important crop because it has high oil content seeds making them biodiesel source (Devappa et al. 2011). Further development of this currently underutilized crop could significantly impact the biodiesel industry. To this end, breeding varieties of $J$. curcas with high yield and high seed oil content are required to increase productivity.

Unfortunately, numerous studies have shown low-level genetic diversity among the $J$. curcas accessions (Saptadi et al. 2011; Saptadi et al. 2017). Breeding for improved $J$. curcas varieties requires the availability of more diverse genetic materials than those available in the germplasm collection; thus, increasing the genetic diversity of $J$. curcas is a priority. Increased genetic diversity could be made possible by interspecific hybridization among Jatropha species. Therefore, the availability of genetic information of related Jatropha species helps validate interspecific $\mathrm{F} 1$ hybrid production successes.
There are five species of Jatropha in Indonesia, including $J$. curcas, J. gossypifolia, J. integerrima, $J$. multifida, and J. podagrica. Members of the Jatropha subgenus have some superior characters, such as high oil content, biotic and abiotic stress tolerance (Asbani 2008; Dhillon et al. 2009). However, those members of the Jatropha sub-genus are generally cultivated as ornamental plants, such as bottle-shrub plants (J. podagrica Hook.), coral plant (J. multifida), bellyache bush (J. gossypifolia L.), spicy Jatropha (J. integerrima Jacq.), and red physic nut (J. montana Willd.) (Terryana et al. 2019). Taxonomically, J. podagrica, J. multifida, J. integerrima, and $J$. gossypifolia belong to the Jatropha subgenus, whereas J. curcas belongs to the Curcas subgenus (Dehgan 1982). Currently, among these species, only J. curcas has been genetically characterized in Indonesia; therefore, genetic evaluations of $J$. podagrica, J. multifida, $J$. integerrima, and J. gossypifolia existed in Indonesia are necessary before they can be fully utilized in interspecific hybridization to introgress the target traits into J. curcas.

Simple Sequence Repeat (SSR) markers or microsatellites are widely used in genetic diversity analysis. SSR is a short repeating sequence abundant in the eukaryotic genome, codominant, and easy to apply (Wang et al. 2014). SSR markers have been widely used for evaluation of the Jatropha spp. germplasm genetic 
diversity (Mastan et al. 2012; Maurya et al. 2013; Montes et al. 2014; Sanou et al. 2015; Saptadi et al. 2017). Even though these SSR markers were developed based on the $J$. curcas genome, they may also be useful for other Jatropha species (Sudheer et al. 2011; Kumar Yadav et al. 2011). Previous studies have indicated that SSR markers may be used for genetic diversity analysis of Jatropha species (Whankaew et al. 2011; Wen et al. 2010). However, we need to determine the evaluated SSR markers' efficiency and effectiveness in evaluating Indonesia's Jatropha species. The study aims to evaluate the transferability of the SSR markers developed from the J. curcas genome to genetically evaluate the accessions of J. multifida, J. integerrima (red and pink flowers), J. podagrica, and $J$. gossypifolia that exist in Indonesia and determine their genetic similarity to J. curcas.

\section{MATERIALS AND METHODS}

Molecular analysis of Jatropha species was carried out in the Plant Molecular Biology Laboratory, Faculty of Agriculture, IPB University, Indonesia. Jatropha leaf samples were collected from various places in Bogor, Indonesia (Table 1). The evaluated SSR primers consisted of 28 primer pairs previously used for J. curcas genetic studies (Saptadi et al. 2011).

The total nucleic acid was isolated from the fresh young leaf $(0.1 \mathrm{~g})$ using CTAB methods described by Sudheer et al. (2009). PCR was performed using a total volume of 25 $\mu \mathrm{L}$, comprised of $0.2 \mu \mathrm{M}$ of each primer, $1.25 \mathrm{U}$ Taq polymerase (Real Biotech Corporation), 1 X PCR buffer, $0.1 \mu \mathrm{M}$ dNTPs $(10 \mathrm{mM}$ mix $)$, and $1 \mu \mathrm{L}$ of DNA template. PCR cycles were run as follows: one cycle of denaturation at $95^{\circ} \mathrm{C}$ for $5 \mathrm{~min}, 36$ cycles of denaturation at $94^{\circ} \mathrm{C}$ for 30 $\mathrm{s}$, primer annealing at the appropriate temperature for each primer for $30 \mathrm{~s}$, primer elongation at $72^{\circ} \mathrm{C}$ for $1 \mathrm{~min}$, and one final cycle extension at $72^{\circ} \mathrm{C}$ for $5 \mathrm{~min}$. The PCR amplified products were separated using $6 \%$ polyacrylamide gel electrophoresis (PAGE) in a Dedicated Height Sequencer (Cole-Parmer). The PAGE separation results were visualized by silver staining, and a 100-bp DNA ladder was used as DNA fragment size controls.

A binary system was applied by scoring 1 for a DNA band and 0 for the absence. The analysis was performed on the binary data to estimate genetic similarity values, as Nei and $\mathrm{Li}$ (1979). The polymorphism percentage (PP) was calculated using the following formula: $\mathrm{PP}=$ total number of polymorphic loci/total number of loci $\times 100$. A dendrogram was produced using Unweight Pair Group Method Arithmetic (UPGMA) with DARwin 6.0.021 (Perrier \& Jacquemoud-Collet 2006). The transferability percentage was calculated as follows: the number of alleles produced in one species/total number of alleles $\times 100$.

\section{RESULTS AND DISCUSSION}

The 28 primers used in this experiment developed from the $J$. curcas genome and confirmed to generate amplified products using a J. curcas DNA (Saptadi et al. 2011). These 28 primers were tested for their ability to amplify SSR markers from four other Jatropha species ( $J$. multifida, J. podagrica, J. gossypifolia, and J. integerrima). Of these 28 primer pairs, 11 primers $(39.3 \%)$ yielded amplified products in four Jatropha species, eight primers $(28.6 \%)$ in three species, and three primers $(10.7 \%)$ in either two or one Jatropha species, respectively. The three remaining primers (EU099519, EU099528, and EU099525, $10.7 \%$ ) did not generate any amplified product using the DNA template of either Jatropha species (Table 2). Examples of SSR marker loci generated using five different SSR primers were presented in Figure 1.

The EU586346 primer pairs yielded a monomorphic band in all species tested. The $J$. podagrica had the highest percentage of cross-species amplification (75\%), while $J$. multifida had the lowest $(57.1 \%$ ) (Table 2). In total, 93 alleles were produced from six plants evaluated, including J. curcas. The number of alleles per primer pairs (Table 2) ranged from 0 (EU099519 primer) to 6 (EU586348) and with an average of 3.5 alleles. The total number of alleles per species ranged from 21 (in J. multifida) to 28 (in $J$. gossypifolia) (Table 2).

Polymorphic information content (PIC) calculated across Jatropha species for the SSR marker loci evaluated ranged from 0 (EU586346, EU099519, and EU099525) to 0.75 (EU099520). Based on their PIC values, five SSR loci (EU586345, EU099534, EU586346, EU099519 and EU099525) belonged to low, eleven were medium (EU586344, EU099527, EU099529, EU586351, EU586340, EU586347, EU099531, EU099521, EU099528, EU099518 and EU586349), and 12 were high PIC values (EU099520, EU099533, EU099526, EU586348, EF612741, EU099523, EU099530, AF469003, EU586343, EU099524, EF612739 and EU099522), respectively (Table 2). The average PIC value across Jatropha species and evaluated SSR loci was 0.48 .

The values of calculated PP ranged from $17.4 \%$ to $62.2 \%$, with an average PP of $38.3 \%$ (Table 3). The lowest PP value was calculated between $J$. podagrica and J. multifida, while the highest was between J. curcas and $J$. gossypifolia (Table 3). Moreover, the calculated genetic dissimilarity coefficient among the evaluated Jatropha species ranged from 0.32 (J. multifida vs. J. gossypifolia) to 0.8 (J. curcas vs. J. podagrica and J. curcas vs. J. gossypifolia) (Table 4).

Table 1. The five Jatropha species used in this study and their centers of origin

\begin{tabular}{|c|c|c|}
\hline Species & $\begin{array}{c}\text { Chromosome } \\
\text { number }{ }^{1)}\end{array}$ & Center of origin \\
\hline Jatropha curcas L. & $2 n=22$ & $\begin{array}{l}\text { Mexico, Central } \\
\text { America }^{2)}\end{array}$ \\
\hline Jatropha multifida $\mathrm{L}$. & $2 n=22$ & Barbados $^{3)}$ \\
\hline Jatropha podagrica L. & $2 n=22$ & $\begin{array}{l}\text { Panama, Honduras, } \\
\text { Guatemala }^{3)}\end{array}$ \\
\hline Jatropha gossypifolia Hook & $2 n=22$ & South America ${ }^{3)}$ \\
\hline Jatropha integerrima Jacq. & $2 n=22$ & 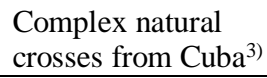 \\
\hline
\end{tabular}

Note: ${ }^{1)}$ Soontornchainaksaeng and Jenjittikul (2003); ${ }^{2)}$ Heller, (1996); ${ }^{3)}$ Dehgan (1982) 
Table 2. PCR cross-amplification results from 28 SSR primers using four Jatropha species genomic DNA template

\begin{tabular}{|c|c|c|c|c|c|c|c|}
\hline \multirow{2}{*}{$\begin{array}{c}\text { Primer } \\
\text { codes }\end{array}$} & \multicolumn{5}{|c|}{ Jatropha species } & \multirow{2}{*}{$\begin{array}{l}\text { Number } \\
\text { of alleles } \\
\text { per locus }\end{array}$} & \multirow{2}{*}{ PIC } \\
\hline & $\mathbf{J M}$ & JIR & JIP & $\mathbf{J P}$ & JG & & \\
\hline 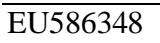 & - & + & + & + & + & 6 & 0.73 \\
\hline EU586340 & + & + & + & + & + & 3 & 0.46 \\
\hline EU586346 & + & + & + & + & + & 1 & 0 \\
\hline EU586347 & + & + & + & + & + & 3 & 0.46 \\
\hline EU586343 & + & + & + & + & + & 5 & 0.68 \\
\hline EU586344 & + & - & - & + & + & 3 & 0.56 \\
\hline EU586345 & + & + & + & + & + & 2 & 0.14 \\
\hline EF612741 & - & + & - & + & + & 5 & 0.71 \\
\hline EF612739 & - & - & - & + & + & 4 & 0.62 \\
\hline EU099518 & - & - & - & + & + & 2 & 0.35 \\
\hline EU099519 & - & - & - & - & - & 0 & 0 \\
\hline EU099520 & + & + & - & + & - & 5 & 0.75 \\
\hline EU099521 & + & + & + & - & + & 3 & 0.41 \\
\hline EU099522 & + & - & + & - & + & 4 & 0.61 \\
\hline EU099523 & - & + & - & - & - & 4 & 0.70 \\
\hline EU099524 & + & + & + & + & + & 4 & 0.65 \\
\hline EU099525 & - & - & - & - & - & 0 & 0 \\
\hline EU099526 & + & - & + & - & - & 5 & 0.74 \\
\hline EU099527 & - & - & - & - & + & 3 & 0.56 \\
\hline EU099528 & - & - & - & - & - & 2 & 0.38 \\
\hline EU099529 & - & + & + & + & + & 3 & 0.50 \\
\hline EU099530 & - & + & - & - & - & 4 & 0.70 \\
\hline EU099531 & + & + & + & + & + & 3 & 0.42 \\
\hline EU099533 & + & + & + & + & + & 6 & 0.75 \\
\hline AF469003 & - & - & + & + & + & 4 & 0.70 \\
\hline EU586351 & + & + & + & + & + & 3 & 0.48 \\
\hline EU586349 & + & + & + & + & + & 2 & 0.35 \\
\hline EU099534 & + & + & + & + & + & 2 & 0.14 \\
\hline $\begin{array}{l}\text { Transfer- } \\
\text { ability (\%) }\end{array}$ & 57.1 & 64.3 & 60.7 & 67.9 & 75.0 & - & \\
\hline $\begin{array}{l}\text { Total } \\
\text { number of } \\
\text { allele }\end{array}$ & 21.0 & 27.0 & 22.0 & 22.0 & 28.0 & 93 & \\
\hline $\begin{array}{l}\text { Note: JM: } \\
\text { integerrima } \\
(+) \text { : amplifi } \\
\text { absence. T } \\
\text { previously b }\end{array}$ & ult & $\begin{array}{l}\text {, J } \\
\text { ver) }\end{array}$ & $J$. & ger & $a(\mathrm{re}$ & $\begin{array}{l}\text { flower), } \\
: J . \text { pod } \\
\text { ed produ }\end{array}$ & $\begin{array}{l}\text { JIP: } J \text {. } \\
\text { agrica; } \\
\text { ct was }\end{array}$ \\
\hline
\end{tabular}

Table 3. Polymorphism percentages calculated from cross-species amplification data of 25 polymorphic SSR marker loci analysis among five Jatropha species

\begin{tabular}{|c|c|c|c|c|c|c|c|}
\hline & Species & 1 & 2 & 3 & 4 & 5 & 6 \\
\hline 1. & J. curcas & - & & & & & \\
\hline 2. & $\begin{array}{l}\text { J. integerrima } \\
\text { (red flower) }\end{array}$ & 49.0 & - & & & & \\
\hline 3. & $\begin{array}{l}\text { J. integerrima } \\
\text { (pink flower) }\end{array}$ & 50.0 & 24.5 & - & & & \\
\hline 4. & J. gossypifolia & 62.2 & 45.9 & 35.7 & - & & \\
\hline 5. & J. multifida & 50.0 & 33.7 & 33.7 & 30.6 & - & \\
\hline 6. & J. podagrica & 49.0 & 32.7 & 28.6 & 31.4 & 17.4 & - \\
\hline
\end{tabular}

Table 4. Dissimilarity matric calculated from the analysis of cross-species amplification data of 25 polymorphic SSR marker loci among five Jatropha species

\begin{tabular}{llcccccc}
\hline & Species & $\mathbf{1}$ & $\mathbf{2}$ & $\mathbf{3}$ & $\mathbf{4}$ & $\mathbf{5}$ & $\mathbf{6}$ \\
\hline 1. & $\begin{array}{l}\text { J. curcas } \\
\text { 2. }\end{array}$ & - & & & & & \\
& $\begin{array}{l}\text { J. integerrima } \\
\text { (red flower) }\end{array}$ & 0.77 & - & & & & \\
3. & J. integerrima & & - & & & & \\
& (pink flower) & 0.75 & 0.41 & - & & & \\
4. & J. gossypifolia & 0.80 & 0.57 & 0.73 & - & & \\
5. & J. multifida & 0.80 & 0.64 & 0.59 & 0.54 & - & \\
6. & J. podagrica & 0.77 & 0.57 & 0.52 & 0.61 & 0.32 & - \\
\hline
\end{tabular}

When using $J$. curcas as an outgroup, the results of the phylogenetic analysis showed the five Jatropha species were divided into three different groups, consisted of Group I $(J$. Gossypifolia, J. multifida and J. podagrica), Group II ( $J$. integerrima red or pink flowers) and Group III (J. curcas). The grouping of Jatropha species based on the dissimilarity distances was presented in Figure 2.

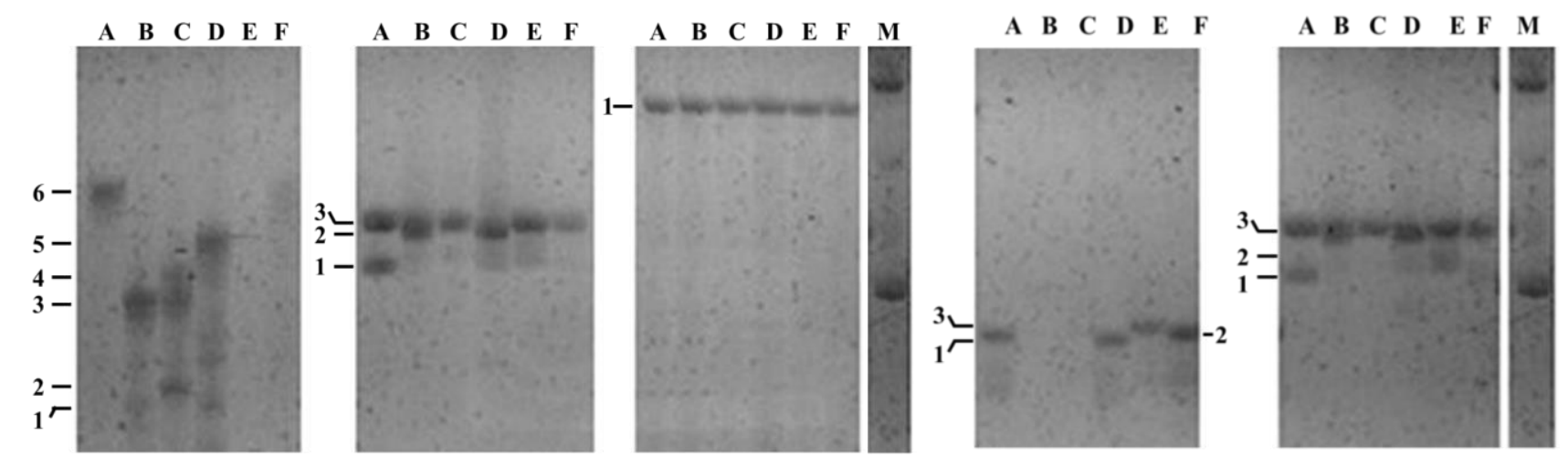

Figure 1. Gel photographs of cross-species amplification by 5 different SSR primer pairs (EU586348, EU586347, EU586346, EU586344, and EU586340) on five Jatropha species (1. J. curcas, 2. J. integerrima Pink Flower, 3. J. integerrima Red Flower, 4. J. gossypifolia, 5. J. multifida and 6. J. podagrica). $\mathrm{M}=100 \mathrm{bp}$ DNA ladder 


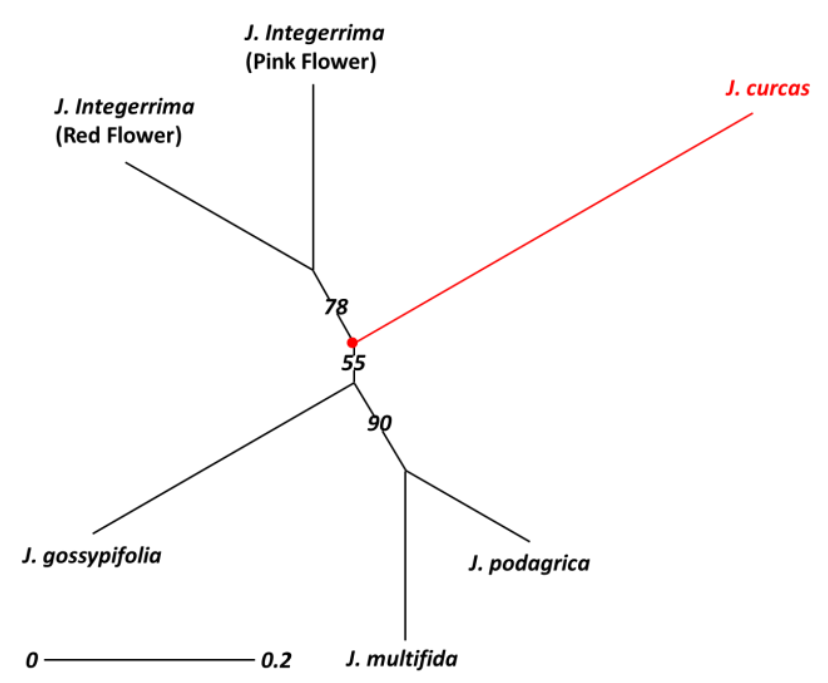

Figure 2. Results of phylogenetic analysis generated from the results of cross-species amplification data of 25 polymorphic SSR marker loci in five Jatropha species. The numbers on the branches showed the bootstrap analysis results

The development of species-specific SSR markers is very costly and time-consuming, so the information on SSR markers for economically less important species is still limited. A strategy that can overcome this problem is to utilize the cross-amplification ability of SSR markers to access the genetic diversity of the related species (Celiński et al. 2013; Aiello et al. 2020). Several studies on the SSR marker transferability were conducted among many taxonomic levels. For example, Datta et al. (2013) reported the successful transfer of SSR markers among Leguminoceae at a maximum rate of $47 \%$. As many as 70 primers from 114 selected SSR markers of Melilotus albus can be used to amplify the markers from 18 other related species (Yan et al. 2017). Moreover, more than $50 \%$ of SSR primers developed from Prosopia chilensis, P. alba, and $P$. flexuosa can amplify the SSR in $P$. cineraria (Rai et al. 2017). In the Jatropha species study, EST SSR primers developed for J. curcas were effective for generating SSR markers of four related Jatropha species at the transferability rate of $75.6-85.2 \%$ (Laosatit et al. 2013).

In the present study, the transferability of $J$. curcas SSRs to other Jatropha species was only $57.1 \%$ to $J$. multifida, $62.5 \%$ to J. integerrima, $67.9 \%$ to $J$. gossypifolia, and $75.0 \%$ to J. podagrica. These results were lower than those reported by Kumar Yadav et al. (2011). In their study, Kumar Yadav et al. (2011) achieved transferability values of $76.0 \%$ to $\mathrm{J}$. multifida, $95.6 \%$ to $\mathrm{J}$. integerrima, $66.6 \%$ to J. gossypifolia, and $57.0 \%$ to $\mathrm{J}$. podagrica, respectively. The rate of transferability for the SSR markers in both the present study and those reported by Kumar Yadav et al. (2011) indicated that the SSR flanking sequences used has a high level of conservation in the genus Jatropha. In general, an increase in the crossamplification success of SSR markers isolated from the cultivated species to the wild species is concomitant with a decline in the genetic distances (Oliveira et al. 2013). This statement is consistent with the results obtained by Koppolu et al. (2010) in Arachis and by Lee et al. (2011) in Allium. The mean percentage of genomic SSR marker transferability in our study was $65 \%$, which was smaller than those reported by Kumar Yadav et al. (2011) for ESTSSRs (an average of 73.65\%). The higher transferability of EST-SSRs than G-SSRs reflected the coding sequences' conservation over the non-coding genomic sequences and the lower frequency of EST mutations over the non-coding genomic sequences (Wen et al. 2010).

The dendrogram presented in Figure 2 supports previous SSR markers analysis results (Sudheer et al. 2011), which grouped J. multifida and J. podagrica into a single group. Morphologically, the flowers of $J$. multifida and $J$. podagrica were very similar in shapes and colors. Moreover, J. curcas and J. integerrima were also more closely related, and this was in agreement with those reported by Terryana et al. (2019). Another report also showed that $J$. curcas and J. integerrima were able to cross-hybridized, which further indicated a taxonomically close relationship between these two species (Maurya \& Yadav 2016).

Considering that the genetic distance between $J$. podagrica and $J$. multifida was closer than that between $J$. curcas and $J$. integerrima, it might be possible to generate interspecific hybrid among J. curcas and J. podagrica as well as J. multifida. Moreover, J. curcas and J. podagrica, as well as $J$. multifida was reported to have the same chromosome numbers (Soontornchainaksaeng et al. 2003). Our dendrogram also shows that J. integerrima (red flower) was genetically the closest to that of J. integerrima (pink flower), which was consistent with the previously reported karyotype study (Soontornchainaksaeng et al. 2003). Based on morphological and biochemical markers, Prabarakan and Sujatha (1999) reported that J. curcas and J. gossypifolia were able to generate a natural interspecific hybrid known as Jatropha tanjorensis. However, our study did not support Prabarakan and Sujatha's (1999) finding since the percentage of polymorphism was quite high between these species $(62.2 \%)$, indicating the two species were distantly related and probably were not able to generate interspecific hybrid. On the other hand, our findings agreed with Avendaño et al. (2015), which showed 79.4 polymorphism percentages between $J$. curcas and $J$. gossypifolia.

In general, the SSR markers used in our study had high transferability values. Even though the genetic similarity values obtained in this study were relatively lower than previous studies, the percentages of polymorphism obtained between J. curcas and other Jatropha species were relatively high. Therefore, our results suggest that the tested SSR markers in this study may be used to estimate the degree of genetic relationship among Jatropha species. Thus, these markers could be used as supporting tools for evaluating the Jatropha species and identifying the interspecific hybrids' progenies among the Jatropha species. 


\section{ACKNOWLEDGMENTS}

We sincerely thank the Ministry of Agriculture, Agency for Agricultural Research and Development (AARD), the Republic of Indonesia, for the funding support through the KKP3T project to this research.

\section{REFERENCES}

Aiello D, Ferradini N, Torelli L, Volpi C, Lambalk J, Russi L, Albertini E. 2020. Evaluation of cross-species transferability of SSR markers in Foeniculum vulgare. Plants 9 (2): 7-9. DOI: 10.3390/plants9020175

Asbani N. 2008. Interspecific hybridization of Jatropha curcas L. and Jatropha integerrima Jaeq. for mites and thrips resistant crops. Pros Lokakarya Nasional III Inovasi Teknologi Jarak Pagar untuk Mendukung Program Desa Mandiri Energi 2008: 96-102. [Indonesian]

Avendaño R, Díaz EG, Valdez-Melara M, Solano NC, Villalobos AM, Cascante FA, Benavides BW, Solís-Ramos LY. 2015. Genetic diversity analysis of Jatropha species from Costa Rica using AFLP markers. Am J Plant Sci 6 (14): 2426-2438. DOI: 10.4236/ajps.2015.614245

Celiński K, Pawlaczyk EM, Wojnicka-Półtorak A, Chudzińska E, PrusGłowacki W. 2013. Cross-species amplification and characterization of microsatellite loci in Pinus mugo Turra. Biologia (Poland) 68 (4) 621-626. DOI: 10.2478/s11756-013-0189-z

Datta S, Mahfooz S, Singh P, Choudhary AK, Chaturvedi SK, Nadarajan N. 2013. Conservation of microsatellite regions across legume genera increases marker repertoire in pigeon pea. Australian J Crop Sci 7 (13): 1990-1997.

Dehgan B. 1982. Novel Jatrophas for Florida Landscapes. Proc Fla State Hort Soc 95: 277-280.

Devappa RK, Makkar HPS, Becker K. 2011. Jatropha diterpenes: A review. J Am Oil Chem Soc 88 (3): 301-322. DOI: 10.1007/s11746010-1720-9.

Dhillon RS, Hooda MS, Jattan M, Chawla V, Bhardwaj M, Goyal SC. 2009. Development and molecular characterization of interspecific hybrids of Jatropha curcas $\times J$. integerrima. Indian J Biotechnol 8: 384-390.

Heller J. 1996. Physic nut. Jatropha curcas L. Promoting the conservation and use of underutilized and neglected crops. 1. In: Physic nut Jatropha curcas L. International Plant Genetic Resources Institute, Rome.

Koppolu R, Upadhyaya HD, Dwivedi SL, Hoisington DA, Varshney RK. 2010. Genetic relationships among seven sections of the genus Arachis studied by using SSR markers. BMC Plant Biol 10: 1-12. DOI: 10.1186/1471-2229-10-15.

Kumar Yadav H, Ranjan A, Asif MH, Mantri S, Sawant SV, Tuli R. 2011 EST-derived SSR markers in Jatropha curcas L.: Development, characterization, polymorphism, and transferability across the species/genera. Tree Genet Genomes 7 (1): 207-219. DOI: 10.1007/s11295-010-0326-6.

Laosatit K, Tanya P, Saensuk, C, Srinives P. 2013. Development and characterization of EST-SSR markers from Jatropha curcas EST database and their transferability across Jatropha-related species/genus. Biologia (Poland) 68 (1): 41-47. DOI: 10.2478/s11756-012-0143-5.

Lee GA, Kwon SJ, Park YJ, Lee MC, Kim HH, Lee JS, Lee SY, Gwag LG, Kim CK, Ma KM. 2011. Cross-amplification of SSR markers developed from Allium sativum to other Allium species. Sci Hortic 128 (4): 401-407. DOI: 10.1016/j.scienta.2011.02.014

Mastan SG, Sudheer PDVN, Rahman H, Ghosh A, Rathore MS, Prakash CR, Chikara J. 2012. Molecular characterization of intra-population variability of Jatropha curcas L. using DNA based molecular markers. Mol Biol Rep 39 (4): 4383-4390. DOI: 10.1007/s11033-0111226-z

Maurya R, Gupta A, Singh SK, Rai KM, Chandrawati, Sawant SV, Yadav HK. 2013. Microsatellite polymorphism in Jatropha curcas L. A biodiesel plant. Ind Crops Prod 49: 136-142. DOI: 10.1016/j.indcrop.2013.04.034.

Maurya R, Yadav HK. 2016. Development of interspecific hybrid of $J$ curcas $x \mathrm{~J}$. integerrima and its molecular characterization using SSR markers. J Agroecol Nat Resour Manage 3 (1): 101-105.

Montes JM, Technow F, Martin M, Becker K. 2014. Genetic diversity in Jatropha curcas L. assessed with SSR and SNP markers. Diversity 6 (3): 551-566. DOI: 10.3390/d6030551.

Oliveira GAF, Pádua JG, Costa JL, de Jesus ON, de Carvalho FM, de Oliveira EJ, Oliveira JL. 2013. Cross-species amplification of microsatellite loci developed for Passiflora edulis Sims. in related Passiflora species. Brazilian Archive Biol Technol 56 (5): 785-792. DOI: 10.1590/S1516-89132013000500009.

Perrier X, Jacquemoud-Collet JP. 2006. DARwin Software. Retrieved from http://darwin.cirad.fr/

Rai MK, Shekhawat JK, Kataria V, Shekhawat NS. 2017. Cross-species transferability and characterization of microsatellite markers in Prosopis cineraria, a multipurpose tree species of Indian Thar desert. Arid Land Res Manag 31 (4): 462-471. DOI: 10.1080/15324982.2017.1338791

Sanou H, Angulo-Escalante MA, Martinez-Herrera J, Kone S, Nikiema A, Kalinganire A, Hansen JK, Kjær ED, Graudal L, Nielsen LR. 2015. Loss of genetic diversity of Jatropha curcas L. through domestication: Implications for its genetic improvement. Crop Sci 55 (2): 749-759. DOI: 10.2135/cropsci2014.02.0165.

Saptadi D, Hartati RS, Setiawan A, Heliyanto B, Sudarsono. 2011. Development of simple sequence repeat markers for Jatropha spp. $\begin{array}{lllll}\text { Jurnal Littri } & 17 & \text { (4): } & 140-149 \text {. } & \text { DOI: }\end{array}$ 10.21082/littri.v17n4.2011.140\%20-\%20149.

Saptadi D, Hartati RS, Setiawan A, Heliyanto B, Sudarsono. 2017. Genetic diversity of Indonesian physic nut (J. curcas) based on molecular markers. Agrivitas 39 (60): 160-171. DOI: 10.17503/agrivita.v39i2.694.

Soontornchainaksaeng P, Jenjittikul T. 2003. Karyology of Jatropha (Euphorbiaceae) in Thailand. Thai For Bull Bot 31: 105-112.

Sudheer PDVN, Mastan SG, Rahman H, Ravi Prakash C, Singh S, Reddy MP. 2011. Cross-species amplification ability of novel microsatellites isolated from Jatropha curcas and genetic relationship with sister taxa: Cross-species amplification and genetic relationship of Jatropha using novel microsatellites. Mol Biol Rep 38 (2): 13831388. DOI: $10.1007 / \mathrm{s} 11033-010-0241-9$.

Terryana RT, Nugroho K, Mulya K, Tasma IM, Lestari P. 2019. Genetic diversity of Jatropha spp. Germplasm based on morphological and molecular markers. Jurnal AgroBiogen 15 (1): 23. DOI: 10.21082/jbio.v15n1.2019.p23-34.

Wang S, Liu Y, Liying M, Liu H, Tang Y, Wu L, Wang Z, Li Y, Wu R, Pang X. 2014. Isolation and characterization of microsatellite markers and analysis of genetic diversity in Chinese jujube (Ziziphus jujuba Mill.). PLoS One 9 (6): e0099842. DOI: 10.1371/journal.pone.0099842

Wen M, Wang H, Xia Z, Zou M, Lu C, Wang W. 2010. Development of EST-SSR and genomic-SSR markers to assess genetic diversity in Jatropha curcas L. BMC Res Notes 3: 42. DOI: 10.1186/1756-05003-42

Whankaew S, Kanjanawattanawong S, Phumichai C, Smith DR, Narangajavana J, Triwitayakorn K. 2011. Cross-genera transferability of (simple sequence repeat) SSR markers among cassava (Manihot esculenta Crantz), rubber tree (Hevea brasiliensis Muell. Arg.) and physic nut (Jatropha curcas L.). Afr J Biotechnol 10 (10): 1768-1776. DOI: $10.5897 / A J B 10.2185$

Yan Z, Wu F, Luo K, Zhao Y, Yan Q, Zhang Y, Wang Y, Zhang J. 2017. Cross-species transferability of EST-SSR markers developed from the transcriptome of Melilotus and their application to population genetics research. Sci Rep 7 (1): 1-11. DOI: 10.1038/s41598-017-18049-8. 